\title{
Dünya Sağlık Örgütü Uluslararası Sitomegalovirüs (CMV) Standardı ile Kalibre Edilmiş íki Ticari Kantitatif CMV Polimeraz Zincir Reaksiyonu Testinin Karşılaştırılması
}

\section{Comparison of Two Commercial Quantitative Cytomegalovirus (CMV) Polymerase Chain Reaction Tests Calibrated by World Health Organization International CMV Standard}

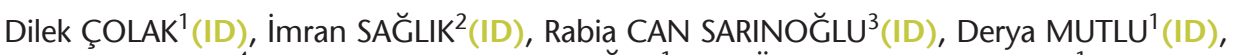

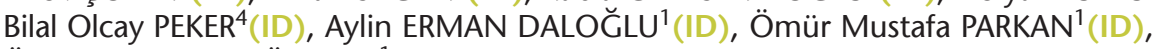
Özlem KOYUNCU ÖZYYURT"1, IID)!,

${ }^{1}$ Akdeniz Üniversitesi Tıp Fakültesi, Tıbbi Mikrobiyoloji Anabilim Dalı, Antalya.

${ }^{1}$ Akdeniz University Faculty of Medicine, Department of Medical Microbiology, Antalya, Turkey.

2 Uludağ Üniversitesi Tıp Fakültesi, Tıbbi Mikrobiyoloji Anabilim Dalı, Bursa.

2 Uludag University Faculty of Medicine, Department of Medical Microbiology, Bursa, Turkey.

${ }^{3}$ Marmara Üniversitesi Pendik Eğitim ve Araştırma Hastanesi, Tıbbi Mikrobiyoloji Kliniği, İstanbul.

${ }^{3}$ Marmara University Pendik Training and Research Hospital, Clinic of Medical Microbiology, Istanbul, Turkey.

${ }^{4}$ Katip Çelebi Üniversitesi Atatürk Eğitim ve Araştırma Hastanesi, Tıbbi Mikrobiyoloji Laboratuvarı, İzmir.

${ }^{4}$ Katip Celebi University Ataturk Training and Research Hospital, Medical Microbiology Laboratory, Izmir, Turkey.

* Bu çalışma, XXXVIII. Türk Mikrobiyoloji Kongresi (4-8 Kasım 2018)'nde sunulmuştur.

Makale Atıfı: Çolak D, Sağlık i, Can Sarınoğlu R, Mutlu D, Peker BO, Erman Daloğlu A ve ark. Dünya Sağlık Örgütü uluslararası sitomegalovirüs (CMV) standardı ile kalibre edilmiş iki ticari kantitatif CMV polimeraz zincir reaksiyonu testinin karşılaştırılması. Mikrobiyol Bul 2020;54(2):257-265.

\section{Öz}

Transplantasyon yapılan hastalarda sitomegalovirüs (CMV) enfeksiyonlarının tanısı, takibi ve antiviral tedavi monitörizasyonunda CMV viral yük saptanması önemlidir. Bu amaçla en yaygın olarak kantitatif polimeraz zincir reaksiyonu kullanılmaktadır. Bu çalışmada, Dünya Sağlık Örgütü (DSÖ) CMV standardı ile kalibre edilmiş ticari testler olan CMV Cobas Ampliprep/Cobas Taqman (CMV-CAP/CTM) (Roche, Almanya) testi ve Artus CMV QIASymphony-Rotorgene (CMV-QS-RGQ) (Qiagen, Almanya) testlerinin sonuçlarının karşılaştııılması amaçlanmıştır. Bu amaçla 244 plazma örneğinde eş zamanlı olarak CMVCAP/CTM ve CMV-QS-RGQ testleri çalışılmıştır. Test sonuçları kopya/ml olarak ölçülmüş, üretici firmaların belirttikleri şekilde, CMV-CAP/CTM testi için 0.91, CMV-QS-RGQ testi için 1.64 ile çarpılarak IU/ml'ye çevrilmiştir. CMV DNA; her iki testte 174 (\%71.3) örnekte saptanmış, 52 (\%21.3) örnekte saptanmamış, 18 (\%7.4) örnekte uyumsuz sonuç elde edilmiştir. Uyumsuzluk saptanan 18 örnekten 16'sında viral yük her iki testin dinamik ölçüm aralıklarının altındadır. CMV-CAP/CTM testi ile CMV DNA saptanamayan bir örnekte CMV-QS-RGQ ile 497 kopya/ml, CMV-QS-RGQ testi ile CMV DNA saptanamayan bir diğer örnekte ise CMV-CAP/CTM testi ile 334 kopya/ml CMV DNA saptanmıştır. Her iki testin kalitatif sonuçları 
arasında yüksek derecede uyum saptanmıştır $(k a p p a=0.80, p<0.001)$. Her iki testin dinamik ölçüm aralığındaki kantitatif sonuçlarda $(n=129)$ CMV-CAP/CTM ve CMV-QS-RGQ testi ile ölçülen ortanca viral yük değerleri sırası ile $1140 \mathrm{kopya} / \mathrm{ml}$ (aralık: 151-254000) ve $1826 \mathrm{kopya} / \mathrm{ml}$ 'dir (aralık: 189-551521). Sonuçlar IU/ml'ye çevrildiğinde CMV-CAP/CTM ve CMV-QS-RGQ testi ile ölçülen ortanca viral yük değerleri sırası ile $1037 \mathrm{IU} / \mathrm{ml}$ (aralık: 137-231140) ve 2993 IU/ml (aralık: 310-904133) olmuştur. CMV-CAP/CTM ve CMV-QS-RGQ testlerinin dinamik ölçüm aralığında elde edilen kantitatif sonuçlarının $(n=129) \log _{10}$ kopya $/ \mathrm{ml}$ ve IU $/ \mathrm{ml}$ değerlerinin; korelasyon analizinde çok kuvvetli korelasyon saptanmıştır (sırası ile $\mathrm{r}=$ $0.94, p<0.001$ ve $r=0.94, p<0.001)$. CMV-CAP/CTM testinde 150, 1000 ve $3000 \mathrm{kopya} / \mathrm{ml}$ değerlerine karşılık gelen CMV-QS-RGQ testi değerleri sırası ile 94.5, 1571 ve 323.5 kopya/ml ve CMV-CAP/CTM testinde yukarıdaki değerlerin IU/ml olarak karşılığı olan 137, 910 ve $2730 \mathrm{IU} / \mathrm{ml}$ değerlerine karşılık gelen CMV-QS-RGQ testi değerleri sırası ile 154, 2557.6 ve $6965.9 \mathrm{IU} / \mathrm{ml}$ 'dir ve bu viral yük değerleri arasında $0.45 \log _{10}$ 'luk bir değişim saptanmıştır. Ancak; her iki testin dinamik ölçüm aralığında sonucu olan 129 örnek ile; CMV DNA, testlerden birinde saptanmazken diğerinde dinamik ölçüm aralığında saptanan iki örnek olmak üzere toplam 131 örnekte; kopya/ml sonuçları için 112 (\%85.5), IU/ml sonuçları için 73 (\%56) örnekte ölçüm farkı $\pm 0.5 \log _{10}$ sınırları içinde, kopya/ml sonuçları için 19 (\%14.5), IU/ml sonuçları için 58 (\%44) örnekte ise ölçüm farkı $\pm 0.5 \log _{10}{ }^{\prime}$ dan fazla olarak gözlenmiştir $(\mathrm{p}<0.001)$. Bland-Altman analizinde CMV-CAP/CTM testi ile CMV-QS-RGQ testinden daha düşük ölçümler yapılmış, kopya/ml ve $\mathrm{IU} / \mathrm{ml}$ sonuçları için sırası ile ortalama fark $0.22 \log _{10} \mathrm{kopya} / \mathrm{ml}$ ve $0.47 \log _{10} \mathrm{IU} / \mathrm{ml}$ olarak bulunmuştur. Sonuç olarak; sonuçlar IU/ml'ye çevrildiğinde her iki test sonucu arasında kabul edilebilir ölçüm farkı (s $0.5 \log _{10}$ ) olan örnek sayısı azalmış, ölçüm farkı > $0.5 \log _{10}$ olan örnek sayısı ise artmış ve aradaki fark istatistiksel olarak anlamlı bulunmuştur $(p<0.001)$. Roche CMV CAP/CTM ve Artus CMV-QS-RGQ testlerinin DSÖ uluslararası CMV standardı ile kalibre edilmesi plazma örneklerinde kantitatif sonuçlar arasında karşılaştırılabilirliği artırmamış, aksine sonuçlar IU/ml'ye çevrildiğinde iki test sonucu arasında biyolojik olarak anlamlı viral replikasyona işaret eden ölçüm farkı saptanmıştır.

Anahtar kelimeler: Sitomegalovirüs; Dünya Sağlık Örgütü; polimeraz zincir reaksiyonu; viral yük.

\section{ABSTRACT}

Cytomegalovirus (CMV) viral load quantitation is important in diagnosis, follow-up, and monitoring of antiviral therapy in transplanted patients. In this study, it was aimed to compare the results of the two commercial World Health Organization (WHO) International CMV standard calibrated polymerase chain reaction tests, CMV Cobas Ampliprep/Cobas Taqman (CMV-CAP/CTM) (Roche, Germany) and Artus CMV QIASymphony-Rotorgene (CMV-QS-RGQ) (Qiagen, Germany). Both tests were performed simultaneously on 244 plasma samples. The results were measured in copies $/ \mathrm{ml}$ and converted to $\mathrm{IU} / \mathrm{ml}$ by multiplying with 0.91 for CMV-CAP/CTM and 1.64 for CMV-QS-RGQ, as specified by the manufacturers. CMV DNA was detected in 174 (71.3\%) and was not detected in $52(21.3 \%)$ of the samples and eighteen (7.4\%) samples had discordant results by both of the tests. In 16 out of 18 samples with discordance, the viral load was below the dynamic measuring ranges of both tests. In one sample, CMV DNA could not be detected by CMV-CAP/CTM but detected by CMV-QS-RGQ with 497 copies/ml, and 334 copies/ $\mathrm{ml} \mathrm{CMV} \mathrm{DNA} \mathrm{was} \mathrm{detected} \mathrm{by} \mathrm{CMV-CAP/CTM} \mathrm{in} \mathrm{another} \mathrm{sample} \mathrm{where} \mathrm{it} \mathrm{could} \mathrm{not} \mathrm{be} \mathrm{detected} \mathrm{by}$ CMV-QS-RGQ. A high degree of agreement was found between the qualitative results of the both tests (kappa $=0.80, p<0.001$ ). For quantitative results in the dynamic measuring range of both assays $(n=$ 129), the median viral load values measured by CMV-CAP/CTM and CMV-QS-RGQ were 1140 copies $/ \mathrm{ml}$ (range: 151-254000) and 1826 copies/ml (range: 189-551521). When the results were converted to IU/ $\mathrm{ml}$, the median viral load values measured by CMV-CAP/CTM and CMV-QS-RGQ were $1037 \mathrm{IU} / \mathrm{ml}$ (range: $137-231140$ ) and $2993 \mathrm{IU} / \mathrm{ml}$ (range: $310-904133$ ), respectively. There was a very strong correlation $\left(r=0.94, p<0.001 ; r=0.94, p<0.001\right.$, respectively) between the $\log _{10}$ values of the quantitative results in the dynamic measuring ranges $(\mathrm{n}=129)$ as copies $/ \mathrm{ml}$ and IU/ml of both tests. CMV-QS-RGQ values corresponding to $150,1000,3000$ copies/ml in CMV-CAP/CTM were as $94.5,1571,323.5$ copies $/ \mathrm{ml}$ and CMV-QS-RGQ values corresponding to 137, 910, $2730 \mathrm{IU} / \mathrm{ml}$ in CMV CAP/CTM were as 154, 2557.6, $6965.9 \mathrm{IU} / \mathrm{ml}$, respectively. A variation of $0.45 \log _{10}$ was determined between these values. In a total of 131 samples; 129 of them with the result of both tests in the dynamic measuring range and two of them 
which CMV DNA was not detected in one of the tests; it was found that $112(85.5 \%)$ results for copy/ $\mathrm{ml}, 73(56 \%)$ results for $\mathrm{IU} / \mathrm{ml}$ were within the measurement difference of $\pm 0.5 \log _{10}$ and $19(14.5 \%)$ results for copy $/ \mathrm{ml}$ and $58(44 \%)$ results for $\mathrm{IU} / \mathrm{ml}$ were greater than $\pm 0.5 \log _{10}$. Bland-Altman analysis showed that CMV-CAP/CTM test made lower measurements than CMV-QS-RGQ and the average difference for copy $/ \mathrm{ml}$ and IU $/ \mathrm{ml}$ results were $0.22 \log _{10}$ copies $/ \mathrm{ml}$ and $0.47 \log _{10} \mathrm{IU} / \mathrm{ml}$. In conclusion; when the results were converted to $\mathrm{IU} / \mathrm{ml}$, the number of samples with an acceptable measurement difference between the two test results $\left(\leq 0.5 \log _{10}\right)$ decreased and the number of samples with a measurement difference $>0.5 \log _{10}$ increased and the difference was found as statistically significant $(p<0.001)$. Calibrating the Roche CMV CAP/CTM and Artus CMV-QS-RGQ tests with the WHO international CMV standard did not increase comparability between quantitative results in plasma samples, on the contrary, it was found that when the results were converted to $\mathrm{IU} / \mathrm{ml}$, a measurement difference indicating biologically significant viral replication was detected between the two test results.

Keywords: Cytomegalovirus; World Health Organization; polymerase chain reaction; viral load.

\section{Giriş}

Solid organ ve kök hücre transplantasyonu yapılan hastalarda sitomegalovirüs (CMV) enfeksiyonlarının tanısı, izlemi ve antiviral tedavi monitörizasyonunda CMV viral yük saptanması önemlidir ${ }^{1}$. Viral yük saptanması CMV antijenemi ve kantitatif polimeraz zincir reaksiyonu (PCR) testleri ile yapılabilmekle birlikte, tüm dünyada, transplantasyon merkezlerinde, ticari ya da laboratuvar tasarımı kantitatif PCR testleri daha çok kullanılmaktadır $^{2-4}$. CMV viral yük tayini yapan testlerde en büyük sorun laboratuvarlar arasındaki sonuçların karşılaştırılabilir olmamasıdır. Aynı örnekteki CMV DNA miktarını farklı gerçek zamanlı PCR (Rt-PCR) testleri farklı ölçmektedir ${ }^{5-7}$. Bu durum; hem aynı hastanın CMV DNA testleri farklı laboratuvarlarda çalışıldığında hem de ülkemizde olduğu gibi birkaç yıllık ihalelerle yapılan alımlarda kit markası değiştiğinde hasta yönetiminde önemli sorunlara yol açacaktır. Dünya Sağlık Örgütü (DSÖ)'nün; testlerde standardizasyonu sağlamak amacı ile geliştirdiği ve 2010 yılında kullanıma sunduğu Uluslararası CMV Standardının klinik örnekler çalışıldığında beklenen standardizasyonu sağlayıp sağlayamadığı konusunda araştırmalar devam etmektedir ${ }^{6-8}$.

Bu çalışmada, DSÖ CMV Standardı ile kalibre edilmiş ticari testler olan CMV Cobas Ampliprep/Cobas Taqman (CMV-CAP/CTM) (Roche Diagnostics, Almanya) testi ile Artus CMV QIASymphony-Rotorgene (CMV-QS-RGQ) (Qiagen, Almanya) testinin sonuçlarının karşılaştırılması amaçlanmıştır. Az sayıdaki makalede DSÖ Uluslararası CMV Standardı ile kalibre edilmiş testler karşılaştırılmıştır ancak CMV-CAP/CTM testi ile Artus CMV-RGQ kiti için QS ekstraksiyon sisteminin kullanıldığı bir çalışma henüz yapılmamıştır.

\section{GEREÇ ve YÖNTEM}

Bu çalışma, Akdeniz Üniversitesi Tıp Fakültesi Klinik Araştırmalar Etik Kurulu onayı ile gerçekleştirildi (Tarih: 03.04.2019 ve Karar no: 324).

Çalışmaya laboratuvarımızda daha önce CMV DNA çalışılıp $-80^{\circ} \mathrm{C}^{\prime}$ de saklanan 244 plazma örneği alındı. Bu örneklerde eş zamanlı olarak CMV-CAP/CTM testi (Roche Diagnostics, Almanya) ve Artus CMV-QS-RGQ (Qiagen, Almanya) testi üretici firmaların önerileri doğrultusunda çalışıldı. Kısaca; 244 plazma örneğinde; nükleik asit ekstraksiyonu eş 
zamanlı olarak CAP ve QS sistemlerinde yapıldıktan sonra sırası ile CMV-CAP/CTM testi ve CMV-QS-RGQ testi ile CMV DNA araştırıldı. CMV-CAP/CTM ve CMV-QS-RGQ testlerinin hedef gen bölgeleri ile amplikon büyüklükleri sırasıyla; UL54 (viral DNA polimeraz) ve IE-2 (UL122) bölgeleri ile 340 baz çifti (bp) ve 105 bp şeklindedir. CMV-CAP/CTM ve CMV-QS-RGQ testlerinin saptama alt sınırı sırası ile $61.5 \mathrm{kopya} / \mathrm{ml}$ ve $42.5 \mathrm{kopya/}$ $\mathrm{ml}$; dinamik aralıkları sırası ile 150-1 × $10^{8} \mathrm{kopya} / \mathrm{ml}$ ve $79.4-1 \times 10^{8} \mathrm{kopya} / \mathrm{ml}$ olarak bildirilmiştir. CMV-CAP/CTM testinde $1 \mathrm{kopya} / \mathrm{ml} 0.91 \mathrm{IU} / \mathrm{ml}^{\prime} \mathrm{ye}, \mathrm{CMV}-\mathrm{QS}-\mathrm{RGQ}$ testinde $1 \mathrm{kopya} / \mathrm{ml} 1.64 \mathrm{IU} / \mathrm{ml}^{\prime}$ ye karşılık gelmektedir. Test sonuçları kopya/ml olarak ölçüldü, belirtilen sayılarla çarpılarak IU/ml değerleri hesaplandı.

Verilerin istatistiksel analizinde SPSS Version 22.0 ve GraphPad Prism Version 8.0. programları kullanıldı. Nonparametrik korelasyon testi Spearman, ROC analizi, BlandAltman ve Fisher'in kesin ki-kare testleri ile veriler analiz edildi, $\mathrm{p}<0.05$ olması anlamlı olarak kabul edildi. Normal dağılım ölçümü için Shapiro-Wilk testi uygulandı.

\section{BULGULAR}

CMV DNA; her iki testte 174 (\%71.3) örnekte pozitif, 52 (\%21.3) örnekte negatif saptanmıştır. Toplam 18 (\%7.4) örnekte uyumsuz sonuç elde edilmiştir (Tablo I). Her iki testin kalitatif sonuçları arasında yüksek derecede uyum saptanmıştır (kappa=0.80, $\mathrm{p}<$ 0.001). CMV DNA, 14 örnekte CMV-CAP/CTM testi ile saptanmış, CMV-QS-RGQ testi ile saptanamamış; dört örnekte ise CMV-QS-RGQ testi ile saptanmış, CMV-CAP/CTM testi ile saptanamamıştır (Tablo I). Uyumsuzluk saptanan bu 18 örnekten 16'sında viral yük her iki testin dinamik ölçüm aralıklarının altındadır. CMV-CAP/CTM testi ile CMV DNA saptanamayan bir örnekte CMV-QS-RGQ ile 497 kopya/ml, CMV-QS-RGQ testi ile CMV DNA saptanamayan bir diğer örnekte ise CMV-CAP/CTM testi ile 334 kopya/ml CMV DNA saptanmıştır.

Her iki testin dinamik ölçüm aralığında elde edilen kantitatif sonuçlar ( $n=129)$ incelendiğinde CMV-CAP/CTM ve CMV-QS-RGQ testi ile ölçülen ortanca viral yük değerleri sırası ile $1140 \mathrm{kopya} / \mathrm{ml}$ (aralık: 151-254000) ve 1826 kopya/ml (aralık: 189-551521) olarak hesaplanmıştır. Sonuçlar IU/ml olarak incelendiğinde CMV-CAP/CTM ve CMV-QS-

\begin{tabular}{|c|c|c|c|c|c|c|}
\hline \multirow[b]{3}{*}{ CMV DNA } & & & \multicolumn{3}{|c|}{ CMV-CAP/CTM testi } & \multirow[b]{3}{*}{ Toplam } \\
\hline & & & \multirow[b]{2}{*}{ Saptanmadı } & \multicolumn{2}{|c|}{ Saptandı (kopya/ml) } & \\
\hline & & & & $\geq 61.5-<150$ & $\geq 150$ & \\
\hline \multirow[t]{3}{*}{ CMV-QS-RGQ testi } & Saptanmadı & & 52 & 13 & 1 & 66 \\
\hline & Saptandı & $\geq 42.5-<79.4$ & 3 & 26 & 5 & 34 \\
\hline & (kopya/ml) & $\geq 79.4$ & 1 & 14 & 129 & 144 \\
\hline Toplam & & & 56 & 53 & 135 & 244 \\
\hline
\end{tabular}


RGQ testi ile ölçülen ortanca viral yük değerleri sırası ile 1037 IU/ml (aralık: 137-231140) ve 2993 IU/ml (aralık: 310-904133) olarak tespit edilmiştir.

CMV-CAP/CTM ve CMV-QS-RGQ testlerinin dinamik ölçüm aralığında elde edilen kantitatif sonuçlarının $(n=129) \log _{10} \mathrm{kopya} / \mathrm{ml}$ ve IU/ml değerlerinin; korelasyon ve Bland-Altman analizleri yapılmıştır. Korelasyon analizine göre her iki testin hem kopya/ $\mathrm{ml}$ hem de IU/ml birimlerinde verilen sonuçlarının karşılaştırılmasında çok kuvvetli korelasyon saptanmıştır (sırası ile $r=0.94, p<0.001$ ve $r=0.94, p<0.001$ ) (Şekil 1). CMVCAP/CTM testinde $150 \mathrm{kopya} / \mathrm{ml}, 1000 \mathrm{kopya} / \mathrm{ml}$ ve 3000 kopya/ml değerlerine karşılık gelen CMV-QS-RGQ testi değerleri ve CMV-CAP/CTM testinde yukarıdaki değerlerin IU/ ml olarak karşıı̆ı olan 137 IU/ml, 910 IU/ml ve $2730 \mathrm{IU} / \mathrm{ml}$ değerlerine karşılık gelen CMV-QS-RGQ testi değerleri Tablo II'de gösterilmiştir. Bu tabloda karşılık geldiği hesaplanan viral yük değerleri arasında en fazla $0.45 \log _{10}{ }^{\prime}$ luk bir değişim saptanmıştır, ayrıca olabilirlik oranları da 10'un üstünde yüksek değerlerdedir. Ancak; her iki testin dinamik ölçüm aralığında sonucu olan 129 örnek ile; CMV DNA, testlerden birinde saptanmazken diğerinde dinamik ölçüm aralığında saptanan iki örnek olmak üzere toplam 131 örnekte; kopya/ml sonuçları için 112 (\%85.5), IU/ml sonuçları için 73 (\%56) örnekte ölçüm farkı $\pm 0.5 \log _{10} \mathrm{kopya} / \mathrm{ml}$ sınırları içinde, kopya/ml sonuçları için 19 (\%14.5), IU/ml sonuçları için ise 58 (\%44) örnekte ölçüm farkı $\pm 0.5 \log _{10}{ }^{\prime}$ dan fazladır (sırası ile ortanca $0.66 \log _{10}$ kopya/ml; aralık: 0.51-2.70 ve ortanca $0.68 \log _{10} \mathrm{IU} / \mathrm{ml}$; aralık 0.51-2.91) $(\mathrm{p}<0.001)$. Testler arasında; kopya/ml değerleri için iki örnekte, IU/ml değerleri için ise altı örnekte \pm $1 \log _{10}$ 'dan fazla ölçüm farkı saptanmıştır.

Her iki testin dinamik ölçüm aralığında elde edilen kopya/ml ve IU/ml birimlerinde hesaplanan kantitatif sonuçların ( $n=129)$ logaritmalarının ortalamalarına karşı farklarının saçılımı Şekil 2'de Bland-Altman plot grafiğinde gösterilmiştir. Buna göre; CMV-CAP/ CTM testi ile CMV-QS-RGQ testinden daha düşük ölçümler yapılmış, ortalama fark 0.22 $\log _{10}$ [standart sapma (SS): 0.28] kopya/ml olarak bulunmuştur. Sonuçlar IU/ml olarak
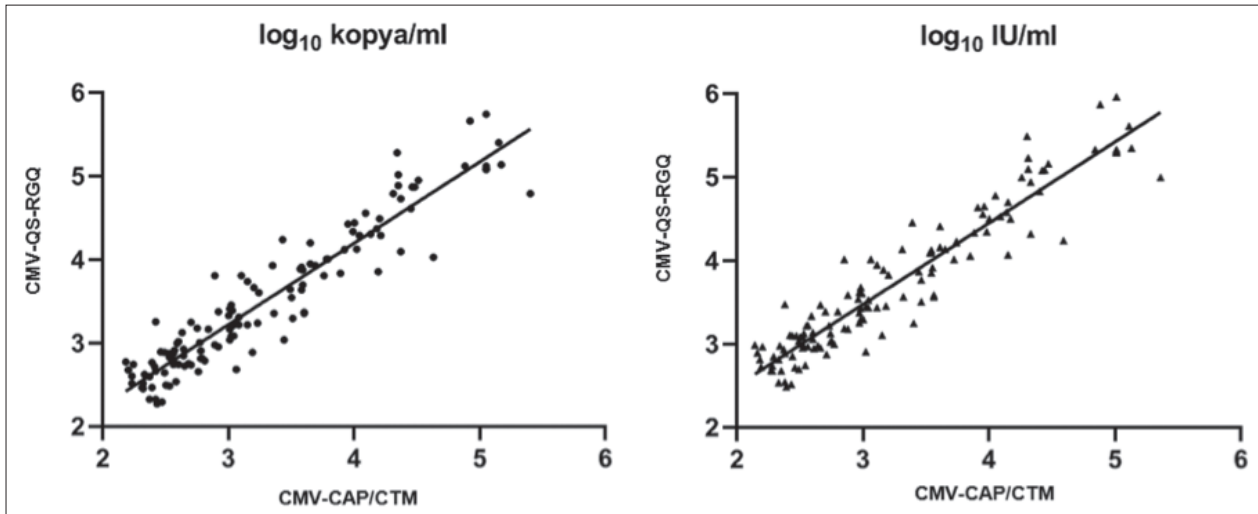

Şekil 1. CMV-CAP/CTM ve CMV-QS-RGQ testlerinde $\log _{10} k$ opya $/ \mathrm{ml}$ ve $\log _{10} \mathrm{IU} / \mathrm{ml}$ birimlerindeki kantitatif sonuçların korelasyon analizi. 


\begin{tabular}{|c|c|c|c|c|c|c|c|}
\hline \multirow[b]{2}{*}{ Testler } & & & \multicolumn{5}{|c|}{ CMV-QS-RGQ } \\
\hline & & & $\begin{array}{l}\text { Karşılık gelen } \\
\text { viral yük }\end{array}$ & $\begin{array}{c}\text { Duyarlılık } \\
\%\end{array}$ & $\begin{array}{c}\text { Özgüllüuk } \\
\%\end{array}$ & EAA & $\begin{array}{c}\text { Pozitif } \\
\text { olabilirlik } \\
\text { oranı (LHR) }\end{array}$ \\
\hline \multirow[t]{6}{*}{ CMV-CAP/CTM } & Kopya/ml & 150 & 94.5 & 99.2 & 98.1 & 0.993 & 52.5 \\
\hline & & 1000 & 1571 & 90.5 & 96.3 & 0.984 & 24.4 \\
\hline & & 3000 & 3233.5 & 94 & 94.7 & 0.988 & 17.7 \\
\hline & $\mathrm{IU} / \mathrm{ml}$ & 137 & 154 & 99.2 & 98.1 & 0.993 & 52.2 \\
\hline & & 910 & 2557.58 & 90.5 & 96.3 & 0.984 & 24.4 \\
\hline & & 2730 & 6965.9 & 92.0 & 95.5 & 0.988 & 20.4 \\
\hline
\end{tabular}
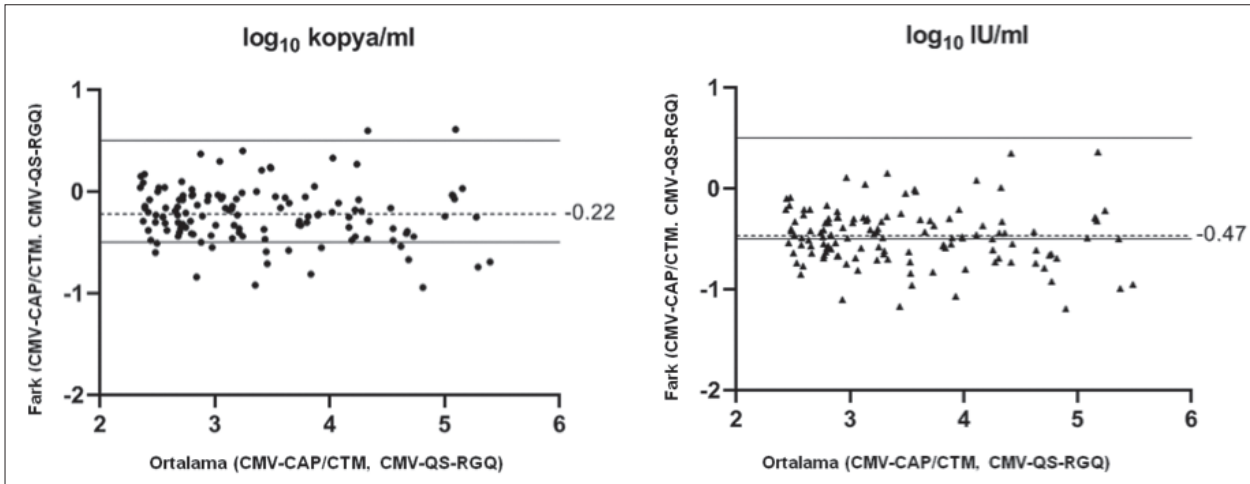

Şekil 2. Roche CMV-CAP/CTMC ve Artus CMV-QS-RGQ testlerinde dinamik ölçüm aralığındaki viral yüklerin $\log _{10}$ değerlerinin ortalamalarına karşı farklarının dağılımının verildiği Bland-Altman grafiği [ $[(a)$ kopya/ml, (b) IU $/ \mathrm{ml}$ ]. Kesikli çizgi ortalama farkı, düz çizgiler $\pm 0.5 \log _{10}$ farkı göstermektedir.

hesaplandığında CMV-CAP/CTM ile daha düşük ölçüm yapıldığı görülmüş ve ortalama fark artarak $0.47 \log _{10}(\mathrm{SS}=0.28) \mathrm{IU} / \mathrm{ml}$ olmuştur (Şekil 2).

\section{TARTIŞMA}

Bu çalışmada, CMV'nin farklı gen bölgelerini hedefleyen; DSÖ Uluslararası CMV Standardı ile kalibre edilmiş, iki ticari CMV PCR testinin kopya/ml ve IU/ml olarak ifade edilen sonuçları karşılaştırılmıştır.

Her iki testin kalitatif sonuçları arasında yüksek derecede uyum saptanmıştır. Uyumsuz örneklerin \%88.9'u testlerin dinamik ölçüm aralıklarının altında zayıf pozitiflik gösteren örneklerdir. Engelmann ve arkadaşlarının ${ }^{3}$ iki ticari CMV PCR testini karşılaştırdıkları çalışmalarında da uyumsuz sonuç veren altı örnekten beşi dinamik ölçüm aralıklarının altında pozitiflik göstermiştir. Preiksaitis ve arkadaşları ${ }^{7}$ düşük ölçüm yapılmasından farklı gB 
tiplerinin sorumlu olabileceğini ve CMV-CAP/CTM testinin bazı gB3 izolatlarında düşük ölçüm yaptığını bildirmişlerdir. Çalışmamızda bir örnekte CMV-QS-RGQ ile 497 kopya/ ml CMV DNA saptanırken, CMV-CAP/CTM testi ile negatif sonuç alınmıştır. Daha önce yaptığımız bir çalışmada hastalarımızdan izole ettiğimiz CMV izolatlarında gB3 genotipi saptanmıştır, bu nedenle CMV DNA saptanmayan bu örnekte de gB3 genotipinin yer alabileceği düşünülmüştür ${ }^{9}$. Diğer yandan CMV-CAP/CTM ile pozitif bulunan bir örnek CMV-QS-RGQ ile negatif çıkmıştır. Farklı testlerde hedeflenen bölgelerde oluşabilecek olası mutasyonlar nedeniyle de ortaya uyumsuz sonuçlar çıkabilmektedir ${ }^{5,10}$. Mannonen ve arkadaşları çalışmalarında ${ }^{10}$ bir hastada CMV-CAP/CTM testi ile laboratuvar tasarımlı CMV PCR testi arasında CMV viral yük kantitasyonunda, başlangıçta paralel gitmekte olan ölçümlerde bir süre sonra $2 \log _{10}$ kopya/ml'ye kadar ulaşan ölçüm farklarının olduğunu gözlemişler ve yaptıkları dizi analizinde laboratuvar tasarımlı CMV PCR testinin hedef gen bölgesinde mutasyon olduğunu saptamışlardır. Çalışmamızda, uyumsuz sonuç veren iki örnek için hedef genlerde dizi analizi yapılamamıştır.

CMV-CAP/CTM ve CMV-QS-RGQ testlerinin dinamik ölçüm aralığında elde edilen kantitatif sonuçların $(n=129) \log _{10} \mathrm{kopya} / \mathrm{ml}$ ve $\log _{10} \mathrm{IU} / \mathrm{ml}$ şeklinde ayrı ayrı değerlerinin korelasyonu incelendiğinde, sonuçlar arasında çok kuvvetli korelasyon ( $r=0.94$ ve $r=0.94$ ) olmasına rağmen; iki farklı testin sonuçlarının birbirlerine yakınlık derecesinin araştırıldığı Bland-Altman analizine göre; CMV-QS-RGQ testi ile yapılan viral yük ölçümleri CMV-CAP/ CTM testine göre daha yüksek bulunmuş ve aradaki fark sonuçlar IU/ml'ye çevrildiğinde artmıştır. Korelasyon analizi ile iki değişken arasında ilişki olup olmadığı, varsa ne yönde ve ne derecede olduğu araştırımaktadır. İki yöntem arasında kuvvetli korelasyon olması sonuçların birbirine yakın olduğu anlamına gelmemektedir. İki farklı testin sonuçlarının birbirlerine yakınlık derecesinin araştııılmasında Bland-Altman analizi olarak tanımlanan; iki testten elde edilen ölçümlerin ortalamalarına karşı farklarının dağılım grafiğinin çizilmesi gerekmektedir. Preiksaitis ve arkadaşlarının DSÖ uluslararası CMV standardı ile kalibre edilmiş 10 farklı kantitatif PCR testi ile yaptıkları çalışmada; primer dizisi kısa olan kitlerde bu oranın daha yüksek miktar saptandığı belirtilmiştir. Çalışmamızda da 105 bp primer dizisi olan CMV-QS-RGQ kiti ile 340 bp primer dizisine sahip CMV-CAP/CTM kitinden daha yüksek miktarlarda ölçüm yapılmıştır. Preiksaitis ve arkadaşları ${ }^{7}$ testin amplikon boyutunun hasta örneklerinde CMV DNA ölçümünü etkilediğini, ancak DSÖ Uluslararası Standardının ölçümlerine etki etmediğini bildirmişlerdir. Plazmadaki serbest CMV DNA'nın fragmante olması küçük amplikonların büyük amplikonlara göre daha fazla çoğalmasına neden olmaktadır ${ }^{11}$. Kısa amplikon oluşturan primerlerle daha yüksek viral yük saptanmaktadır, çalışmamızda da küçük amplikon oluşturan Artus CMV-QS-RGQ testi ile daha yüksek viral yük saptanmıştır. Plazmadaki küçük fragmanlar uzun amplikon ölçümü yapan testlerle saptanamayabilir. Muhtemelen hastaların plazma örneklerinde CMV daha fragmante olarak bulunmaktadır, hücre kültürlerinden hazırlanan DSÖ uluslararası CMV standardı ise intakt virüs içermektedir. Çalışmamızda DSÖ Uluslararası CMV Standardının farklı dilüsyonları çalışılmamıştır.

CMV DNA ölçümü yapan PCR testlerinde viral yük değişiminde iki ölçüm arasındaki farkın > $0.5 \log _{10}$ olmasının viral replikasyonda önemli değişiklik göstergesi olduğu belir- 
tilmiştir ${ }^{12}$. Çalışmamızda sonuçlar kopya/ml olarak verildiğinde iki test sonucu arasındaki ölçüm farkı > $0.5 \log _{10}$ olan örnek sayısı 19 (\%14.5) iken, sonuçlar IU/ml'ye çevrildiğinde iki test sonucu arasındaki ölçüm farkı > $0.5 \log _{10}$ olan örnek sayısı artarak 58 (\%44) olmuştur ve aradaki fark istatistiksel olarak anlamlı bulunmuştur. Buna göre çalışığımız iki testin DSÖ uluslararası CMV standardı ile kalibre edilmesi; bu iki test arasında plazmadan elde edilen kantitatif sonuçların karşılaştııılabilirliğini artırmamıştır. Hayden ve arkadaşları ${ }^{6}$ DSÖ uluslararası CMV standardı ile kalibre edilmiş farklı testlerde standardın çeşitli dilüsyonları çalışıldığında gözlenen matematiksel ilişkinin klinik örnekler çalışıldığında gözlenmediğini, oysa bir standardın yeterli kabul edilebilmesi için hem standart hem de klinik örnekler test edildiğinde aynı matematiksel ilişkinin gözlenmesi gerektiğini belirtmektedirler. Preiksaitis ve arkadaşlarının çalışmasında ${ }^{7}$; doku kültürlerinde hazırlanan DSÖ uluslararası CMV standardının çeşitli dilüsyonlarında yaptıkları ölçümler arasında yüksek derecede uyum saptanırken; bulgularımıza benzer olarak, hasta örneklerinin sadece $\% 58.9$ 'unun kabul edilebilir fark olan $\pm 0.5 \log _{10} \mathrm{IU} / \mathrm{ml}$ sınıları içerisinde bulunduğunu belirtmektedirler. Mannonen ve arkadaşları ${ }^{10}$ Roche CMV-CAP/CTM testi ve laboratuvar tasarımlı bir CMV PCR testini karşılaştırmışlar, kopya/ml biriminde verilen sonuçlarda sonuçlarımızla benzer olarak örneklerin \%81'inde sonuçlar arasındaki farkın kabul edilebilir sınırlar içinde olduğunu, sonuçlar IU/ml'ye çevrildiğinde ise bu oranın \%9'a düştüğünü bildirmişlerdir. DSÖ uluslararası CMV standardı ile kalibrasyon sonucunda, sonuçlar IU/ ml'ye çevrildiğinde uyumsuzluğun arttığı Engelmann ve arkadaşları ${ }^{3}$ tarafından da bildirilmiştir.

Ulaşılabildiği kadarı ile Roche CMV-CAP/CTM ve Artus CMV-QS-RGQ sistemlerinden elde edilen sonuçların IU/ml'ye çevrilmesiyle hesaplanan değerlerin karşılaştıııldığı bir çalışma bugüne kadar yapılmamıştır, sunduğumuz çalışma bu konuda ilktir. Preiksaitis ve arkadaşları ${ }^{7}$ CMV-CAP/CTM ile Artus CMV-RG kitini karşıllaştırmışlar ancak ekstraksiyon aşamasında QS yerine aynı üretici firmanın başka bir ekstraksiyon cihazını (EZ1 Advanced, Qiagen, Almanya) kullanmışlardır. Hoteit ve arkadaşlarının Roche CMV-CAP/CTM ve Artus CMV-RG kitini karşılaştırdıkları çalışmalarında ${ }^{13}$ Artus CMV-RG kiti için kullandıkları manual ekstraksiyon yöntemi (High Pure Viral Nucleic Acid Kit, Roche Diagnostics) çalışmamızdan farklıdır, çalışmada ayrıca kopya/ml biriminden sonuçları değerlendirilmiştir. Ekstraksiyon kitlerinin sonuçlara etki ettiği iyi bilinmektedir ${ }^{14,15}$.

Bu çalışmada elde edilen sonuçlar sadece plazma örnekleri için geçerli olup, tam kan, beyin omurilik sıvısı, idrar gibi diğer klinik örneklere uyarlanmamalıdır.

Sonuç olarak; Roche CMV-CAP/CTM ve Artus CMV-QS-RGQ testlerinin DSÖ uluslararası CMV standardı ile kalibre edilmesi plazma örneklerinde kantitatif sonuçlar arasında karşılaştıılabilirliği artırmamış, aksine sonuçlar IU/ml'ye çevrildiğinde iki test sonucu arasında biyolojik olarak anlamlı viral replikasyona işaret eden ölçüm farkı saptanmıştı. Bu durumun; aynı hastanın CMV DNA testleri farklı laboratuvarlarda çalışıldığında, laboratuvarlarda çalışılan CMV DNA kitlerinin markaları değiştiğinde hasta yönetiminde önemli sorunlara yol açabileceği akılda tutulmalıdır. DSÖ Uluslararası CMV Standardının klinik 
örneklerde kullanımında iyileşme sağlanana kadar elde edilen sonuçlar teste özgül olarak değerlendirilmelidir.

\section{ÇIKAR ÇATIŞMASI}

Yazarlar bu makale ile ilgili herhangi bir çıkar çatışması bildirmemişlerdir.

\section{KAYNAKLAR}

1. Kotton CN, Kumar D, Caliendo AM, Huprikar S, Chou S, Danziger-Isakov L, et al. The third international consensus guidelines on the management of cytomegalovirus in solid-organ transplantation. Transplantation 2018; 102(6): 900-31.

2. Özkarataş E, Özbek ÖA, Avkan Oğuz V, Sayiner AA. Comparison of the CMV antigenemia test and CMV-DNA PCR results in solid organ transplant recipients. Mikrobiyol Bul 2016; 50(1): 44-52.

3. Engelmann I, Alidjinou EK, Lazrek M, Ogiez J, Pouillaude JM, Chazard E, et al. Comparison of two commercial quantitative PCR assays and correlation with the first WHO international standard for human CMV. Diagn Microbiol Infect Dis 2018; 91(1): 27-33.

4. Natori Y, Alghamdi A, Tazari M, Miller V, Husain S, Komatsu T, et al. Use of viral load as a surrogate marker in clinical studies of cytomegalovirus in solid organ transplantation: A systematic review and meta-analysis. Clin Infect Dis 2018; 66(4): 617-31.

5. Pang XL, Fox JD, Fenton JM, Miller GG, Caliendo AM, Preiksaitis JK, et al. Interlaboratory comparison of cytomegalovirus viral load assays. Am J Transplant 2009; 9(2): 258-68.

6. Hayden RT, Preiksaitis J, Tong Y, Pang X, Sun Y, Tang L, et al. Commutability of the first world health organization international standard for human cytomegalovirus. J Clin Microbiol 2015; 53(10): 3325-33.

7. Preiksaitis JK, Hayden RT, Tong Y, Pang XL, Fryer JF, Heath AB, et al. Are we there yet? Impact of the first international standard for Cytomegalovirus DNA on the harmonization of results reported on plasma samples. Clin Infect Dis 2016; 63(5): 583-9.

8. Hirsch HH, Lautenschlager I, Pinsky BA, Cardenoso L, Aslam S, Cobb B, et al. An international multicenter performance analysis of cytomegalovirus load tests. Clin Infect Dis 2013; 56(3): 367-73.

9. Eren Dağlar D, Öngüt G, Çolak D, Özkul A, Mutlu D, Zeytinoğlu A, et al. Türkiye'de farklı coğrafi bölgelerde ve farklı hasta gruplarındaki sitomegalovirüs izolatlarının glikoprotein B genotiplerinin belirlenmesi. Mikrobiyol Bul 2016; 50(1): 53-62.

10. Mannonen L, Loginov R, Helantera I, Dumoulin A, Vilchez RA, Cobb B, et al. Comparison of two quantitative real-time CMV-PCR tests calibrated against the 1 st WHO international standard for viral load monitoring of renal transplant patients. J Med Virol 2014; 86(4): 576-84.

11. Boom R, Sol CJA, Schuurman T, Van Breda A, Weel JFL, Beld M, et al. Human cytomegalovirus DNA in plasma and serum specimens of renal transplant recipients is highly fragmented. J Clin Microbiol 2002; 40(11): 4105-13.

12. Kraft CS, Armstrong WS, Caliendo AM. Interpreting quantitative cytomegalovirus DNA testing: understanding the laboratory perspective. Clin Infect Dis 2012; 54(12): 1793-7.

13. Hoteit R, Fermanian P, Abbas F, Abdel Khalek R, Mahfouz R. Comparison of the Artus RotorGene and COBAS Ampliprep/COBAS TaqMan platforms for the detection of cytomegalovirus: experience of a tertiary care center. Genet Test Mol Biomarkers 2016; 20(4): 167-9.

14. Kim H, Hur M, Kim JY, Moon HW, Yun YM, Cho HC. Automated nucleic acid extraction systems for detecting cytomegalovirus and Epstein-Barr virus using real-time PCR: A comparison study between the QIAsymphony RGQ and QIAcube Systems. Ann Lab Med 2017; 37(2): 129-36.

15. Cook L, Starr K, Boonyaratanakornkit J, Hayden R, Sam SS, Caliendo AM. Does size matter? Comparison of extraction yields for different-sized DNA fragments by seven different routine and four new circulating cellfree extraction methods. J Clin Microbiol 2018;56(12): e01061-18. 